\title{
Prevalence of thyroid dysfunction in pregnant women and the need for universal screening: an observational study in Northern Andhra Pradesh population
}

\author{
Krishnamma B. ${ }^{1}$, Prabhavathi V. ${ }^{1}$, Prasad D. K. V. ${ }^{2 *}$
}

${ }^{1}$ Department of Obstetrics and Gynecology, ${ }^{2}$ Department of Biochemistry, NRI Institute of Medical Sciences, Sangivalasa, Visakhapatnam, Andhra Pradesh, India

Received: 04 April 2017

Accepted: 02 May 2017

*Correspondence:

Dr. Prasad D. K. V.,

E-mail: drprasaddkv@yahoo.co.in

Copyright: (c) the author(s), publisher and licensee Medip Academy. This is an open-access article distributed under the terms of the Creative Commons Attribution Non-Commercial License, which permits unrestricted non-commercial use, distribution, and reproduction in any medium, provided the original work is properly cited.

\begin{abstract}
Background: The maternal thyroid dysfunction is associated with adverse outcomes such as miscarriage, preterm delivery, preeclampsia, postpartum haemorrhage in mother whereas increased risk of impaired neurological development in foetus. The present study was designed with an aim to determine the prevalence of thyroid dysfunction and the need for universal screening in pregnant women.

Methods: Three hundred and eighty pregnant women between 8-36 weeks of gestation with age group 20-32 years were recruited. Serum free T3, free T4 and TSH levels were assayed by chemiluminescence method. The pregnant women were classified into euthyroid, subclinical hypothyroid $(\mathrm{SH})$, overt hypothyroid $(\mathrm{OH})$ and overt hyperthyroid groups based on the results obtained in the study.

Results: In the present study, the mean \pm SD age (in years) and BMI of all pregnant women was $23.9 \pm 3.9$ and $22.9 \pm 1.6$ respectively. The maternal age was high in $\mathrm{OH}$ and overt hyperthyroid and was statistically significant $(\mathrm{p}<0.05)$. Similarly, women with high BMI were prone to $\mathrm{OH}$ than normal BMI $(\mathrm{p}<0.05)$. The prevalence of thyroid dysfunction was found to be $18.7 \%$. The prevalence of hypothyroidism was $17.4 \%$ in which the SH was $13.4 \%$ and overt hypothyroidism $3.9 \%$, but overt hyperthyroidism was $1.3 \%$. TSH levels increased with the advancement of gestational age from $2.72 \pm 1.85$ in first trimester to $3.4 \pm 2.05 \mu \mathrm{IU} / \mathrm{mL}$ in third trimester, and the difference was statistically significant $(\mathrm{p}<0.05)$. Finally, it was also noticed that the prevalence of raised TSH in high-risk pregnant women was high compared to low-risk women (35.6\% vs $5.1 \%$ ) relative risk (RR) $7.64,95 \%$ confidence interval (CI) 4.62-12.65, (p<0.0001). However, 14 out of 51 (27.5\%) with SH were in low-risk group.

Conclusions: The present study states that the prevalence of thyroid dysfunction was $18.7 \%$ and also emphasizes the importance of screening all pregnant women for thyroid dysfunction rather than targeted high-risk pregnant women to prevent both maternal and fetal morbidity.
\end{abstract}

Keywords: Hypothyroidism, Thyroid dysfunction, Thyroid stimulating hormone, Subclinical hypothyroidism

\section{INTRODUCTION}

During pregnancy, thyroid gland undergoes reversible physiological changes such as increase in size (by 10\%) and increased vascularization etc. due to the influence of
$\beta$-hCG since first trimester. ${ }^{1}$ The circulating levels of thyroid binding globulin (TBG) are also increased due to increased hepatic synthesis and prolongation of its halflife from 15 minutes to 3 days which is an estrogen mediated. $^{2}$ Due to the structural analogy with 
thyroidstimulating hormone (TSH), $\beta$-hCG causes thyroid stimulation. The increased renal clearance both fetal intake and placenta metabolism promote a relative risk decline in the availability of iodide. In general, the pregnant women have lower free $T_{3}\left(\mathrm{fT}_{3}\right)$ and free $\mathrm{T}_{4}$ $\left(\mathrm{fT}_{4}\right)$ levels at term than non-pregnant women. ${ }^{3,4}$ In India, the incidence of hypothyroidism ranges between 4.8 $11 \% .^{5}$ The maternal thyroid dysfunction associated with adverse outcomes such as miscarriage, preterm delivery, eclampsia, preeclampsia and placental abruption in mother whereas increased risk of impaired neurological development in fetus. ${ }^{6}$ So thyroid function is affected by pregnancy and its dysfunction effects maternal and fetal morbidity.

About $0.5 \%$ of all pregnant women will suffer from overt hypothyroidism, defined as an elevated TSH levels with decreased $\mathrm{fT}_{4}$ levels. ${ }^{7}$ Chronic autoimmune thyroiditis (Hashimoto's thyroiditis) is the most common etiology for this problem in pregnancy and the other causes include endemic iodide deficiency and prior radioactive iodine therapy or thyroidectomy. If uncorrected, the overt hypothyroidism in pregnancy has been associated with increased risk for premature birth, low birth weight and miscarriage. The subclinical hypothyroidism is defined as an elevated TSH level with a normal level of circulating fT4 levels. ${ }^{8}$ The prevalence of subclinical hypothyroidism during pregnancy in US is $0.25-2.5 \%$ whereas in India according to Sahu et al. the prevalence of was $6.5 \% .^{9,10}$ As the pregnancy is a hypermetabolic state, it can mask the symptoms of hypothyroidism and subclinical hypothyroidism. The studies showing the prevalence of overt, subclinical hypothyroidism and the significance of TSH levels in pregnant women are lacking in our population. Hence, the present study was aimed to know the frequency of overt and subclinical hypothyroidism in Northern Andhra Pradesh population and the need for universal screening in pregnancy for thyroid dysfunction.

\section{METHODS}

The present study was performed in the department of obstetrics and gynecology in association with department of Biochemistry at Anil Neerukonda Hospital, between Mar 2016 and Mar 2017 after ethical clearance from the Institutional Ethics Committee.

A total of 380 pregnant women between age group 20-33 years who visited our hospital for antenatal check-up were recruited for the study with their written informed consent. All healthy pregnant women between 8-28 weeks of gestation $(<12$ weeks $n=150,>12-24$ weeks $\mathrm{n}=130$ and $>24$ weeks $\mathrm{n}=100$ ) irrespective of the gravida were included in the study. Apart from detailed history and clinical examination, serum $\mathrm{fT}_{3}, \mathrm{fT}_{4}$ and $\mathrm{TSH}$ levels were measured by fully automated electrochemiluminescent immunoassay using commercially available kits from bioMerieux SA with Vidas analyzer. The reference range used in the study was based on the manufacturer's manual for diagnosis of thyroid dysfunction during pregnancy $\left(1^{\text {st }}\right.$ trimester- $\mathrm{fT}_{3} 1.93$ $5.89 \mathrm{pg} / \mathrm{mL}, \mathrm{fT}_{4} 0.94-1.52 \mathrm{ng} / \mathrm{mL}$ and $\mathrm{TSH} 0.6-5.0$ $\mu \mathrm{IU} / \mathrm{mL} ; 2^{\text {nd }}$ trimester- $\mathrm{fT}_{3} 2.6-5.75 \mathrm{pg} / \mathrm{mL}, \mathrm{fT}_{4} 0.74-1.53$ $\mathrm{ng} / \mathrm{mL}$ and TSH 0.4-6.0 $\mu \mathrm{IU} / \mathrm{mL} ; 3^{\text {rd }}$ trimester- $\mathrm{fT}_{3} 3.31-$ $5.20 \mathrm{pg} / \mathrm{mL}, \mathrm{fT}_{4} 0.88-1.38 \mathrm{ng} / \mathrm{mL}$ and $\mathrm{TSH} \quad 0.7-6.0$ $\mu \mathrm{IU} / \mathrm{mL})$.

\section{RESULTS}

All the recruited 380 pregnant women $\left(1^{\text {st }}\right.$ trimester 150 , $2^{\text {nd }}$ trimester 130 and $3^{\text {rd }}$ trimester 100$)$ were divided into four groups viz. euthyroid, overt hypothyroid, subclinical hypothyroid and overt hyperthyroid according to the results obtained in the present study. Euthyroid defined as the pregnant women with normal $\mathrm{TSH}$ and normal $\mathrm{fT}_{4}$ levels, overt hypothyroid, defined as the subject having low $\mathrm{fT}_{4}$ with high $\mathrm{TSH}$, subclinical hypothyroid, defined as normal $\mathrm{fT}_{4}$ with high $\mathrm{TSH}$ levels and overt hyperthyroidism, defined as high $\mathrm{fT}_{4}$ with low $\mathrm{TSH}$ values. Demographic characteristics of pregnant women are summarized in Table 1.

\section{Table 1: Demographic characteristics of pregnant women $(n=380)$.}

\begin{tabular}{|c|c|}
\hline Characteristics & Mean \pm SD \\
\hline Maternal age (in years) (Mean \pm SD) & $23.94 \pm 3.9$ \\
\hline BMI $\left(\mathrm{kg} / \mathrm{m}^{2}\right)($ Mean \pm SD $)$ & $22.97 \pm 1.63$ \\
\hline \multicolumn{2}{|l|}{ Gestational age at screening, $\mathrm{n}(\%)$} \\
\hline$\leq 12$ wks & $150(39.5 \%)$ \\
\hline$>12 \mathrm{wks}-\leq 24 \mathrm{wks}$ & $130(34.2 \%)$ \\
\hline$>24$ wks & $100(26.3 \%)$ \\
\hline \multicolumn{2}{|l|}{ History of previous pregnancy, $\mathrm{n}(\%)$} \\
\hline None (primi) & $150(39.5 \%)$ \\
\hline One pregnancy & $110(29.8 \%)$ \\
\hline Two pregnancy & $42(11.1 \%)$ \\
\hline$>2$ pregnancy & $78(20.5 \%)$ \\
\hline History of previous miscarriage, $\mathrm{n}(\%)$ & $83(22.3 \%)$ \\
\hline $\begin{array}{l}\text { Personal history of thyroid disease, } \mathrm{n} \\
(\%)\end{array}$ & $20(5.3 \%)$ \\
\hline T4 replacement therapy, n (\%) & $6(1.57 \%)$ \\
\hline Family history of thyroid disease, $\mathrm{n}(\%)$ & $76(20 \%)$ \\
\hline $\begin{array}{l}\text { Personal history of other autoimmune } \\
\text { diseases, } n(\%)\end{array}$ & $2(0.5 \%)$ \\
\hline
\end{tabular}

The mean \pm SD age (in years) and BMI $\left(\mathrm{kg} / \mathrm{m}^{2}\right)$ of all the pregnant women was $23.9 \pm 3.9$ and $22.9 \pm 1.6$ respectively. Out of 380 pregnant women screened, we found the prevalence of thyroid dysfunction in the present study was $23.14 \%$. Among this, the prevalence of hypothyroidism was $21 \%$ out of which $5.26 \%$ had overt hypothyroidism and $15.78 \%$ had subclinical hypothyroidism. The prevalence of hyperthyroidism was $2.1 \%$ whereas no pregnant women was identified with subclinical hyperthyroidism (Table 2). The mean \pm SD BMI for euthyroid patients, subclinical hypothyroid, overt hypothyroid and overt hyperthyroid pregnant women were $22.9 \pm 1.5,23.6 \pm 1.4,25.2 \pm 1.28$ and $20.3 \pm 0.7$ respectively. Similarly, the mean age $\pm \mathrm{SD}$ for euthyroid 
was 23.9 \pm 3.6 , subclinical hypothyroid was $24.6 \pm 4.52$, overt hypothyroid was $27.2 \pm 5.1$ and overt hyperthyroid was $29.1 \pm 1.2$ (Table 2 ). The pregnant women with more BMI had higher TSH levels (overt hypothyroid) (Table 2).

Table 2: Obstetrical variable in antenatal period.

\begin{tabular}{|c|c|c|}
\hline Groups & $\begin{array}{l}\text { Age } \\
(\text { Mean } \pm \text { SD })\end{array}$ & $\begin{array}{l}\text { BMI } \\
(\text { Mean } \pm \text { SD) }\end{array}$ \\
\hline Euthyroid (n=309) & $23.6 \pm 3.6$ & $22.8 \pm 1.6$ \\
\hline $\begin{array}{l}\text { Subclinical hypothyroid } \\
(\mathrm{n}=51)\end{array}$ & $24.3 \pm 4.5$ & $23.6 \pm 1.4$ \\
\hline $\begin{array}{l}\text { Overt hypothyroid } \\
(\mathrm{n}=15)\end{array}$ & $27.3 \pm 5.1$ & $25.2 \pm 1.28 *$ \\
\hline $\begin{array}{l}\text { Overt hyperthyroid } \\
(\mathrm{n}=5)\end{array}$ & $29.1 \pm 1.2 *$ & $20.3 \pm 0.7 *$ \\
\hline
\end{tabular}

Note: ${ }^{*} \mathrm{p}<0.05$ significant
The mean \pm SD values for the fT3, fT4 and TSH between each trimester showed no significant variation in fT3 and fT4 levels.

However, TSH showed significant difference among trimesters with levels increased with advancement of gestational age $(\mathrm{p}<0.05)$ (Table 3$)$.

Table 3: Serum concentrations of fT3, fT4 and TSH in different trimesters of pregnancy.

\begin{tabular}{|lllll|} 
& $\begin{array}{l}\text { I } \\
\text { trimester } \\
(\mathrm{n}=150)\end{array}$ & $\begin{array}{l}\text { II trimester } \\
(\mathrm{n}=130)\end{array}$ & $\begin{array}{l}\text { III } \\
\text { trimester } \\
(\mathrm{n}=100)\end{array}$ & $\begin{array}{l}\mathrm{p} \text { - } \\
\text { value }\end{array}$ \\
\hline fT3 & $2.8 \pm 0.46$ & $2.84 \pm 0.48$ & $2.86 \pm 0.46$ & $\mathrm{NS}$ \\
\hline fT4 & $1.28 \pm 0.85$ & $1.24 \pm 0.77$ & $1.23 \pm 0.87$ & $\mathrm{NS}$ \\
\hline TSH & $2.72 \pm 1.85$ & $3.05 \pm 2.13$ & $3.5 \pm 2.05$ & $0.01 *$ \\
\hline
\end{tabular}

Note: $\mathrm{p}$-value $<0.05 *$ is significant; NS-not significant

Table 4: Comparison of thyroid status in high-risk and low-risk pregnant women.

\begin{tabular}{|lllll|} 
& $\begin{array}{l}\text { Normal TSH, } \\
\text { normal fT4 } \\
\text { Category }\end{array}$ & $\begin{array}{l}\text { Raised TSH, } \\
\text { Normal fT4 } \\
\text { (Subclinical- } \\
\text { Hypothyroid) }\end{array}$ & $\begin{array}{l}\text { Raised TSH, } \\
\text { low fT4 } \\
\text { (Overt } \\
\text { hypothyroid) }\end{array}$ & $\begin{array}{l}\text { Low TSH, } \\
\text { high fT4 } \\
\text { (Overt } \\
\text { hyperthyroid) }\end{array}$ \\
\hline All subjects $(\mathrm{n}=380)$ & $309(81.3 \%)$ & $51(13.4 \%)$ & $15(3.9 \%)$ & $5(1.3 \%)$ \\
\hline Low risk pregnant women $(\mathrm{n}=276)$ & $259(93.8 \%)$ & $14(5.1 \%)$ & $3(1.1 \%)$ & - \\
\hline High-risk pregnant women $(\mathrm{n}=104)$ & $50(48.1 \%)$ & $37(35.6 \%)$ & $12(11.5 \%)$ & $5(4.8 \%)$ \\
\hline
\end{tabular}

\section{DISCUSSION}

Several factors are responsible for the thyroid dysfunction during various stages of pregnancy. In general, during $1^{\text {st }}$ trimester $\mathrm{fT}_{4}$ increase with suppression of $\mathrm{TSH}$ in response to placental human chorionic gonadotropin, while $\mathrm{fT}_{4}$ tends to decrease in later stages of gestation. This may be possible cause for the higher incidence of hypothyroidism in the $1^{\text {st }}$ trimester compared to the $2^{\text {nd }}$ and $3^{\text {rd }}$ trimesters. Hypothyroidism is defined as an elevated TSH level with a low $\mathrm{fT}_{4}$ level. According to ACOG, the prevalence of hypothyroidism in pregnancy is $2-5 \%$ where as in India it ranges from 4.8-11\%..$^{5}$ During pregnancy, there has been a wide geographic variation from $2.5 \%$ from the West to $11 \%$ from India in prevalence of hypothyroidism. ${ }^{11,12}$ It seems that prevalence of hypothyroidism is more in Asian countries when compared to the West. ${ }^{13}$ In the present study, we found that the prevalence of hypothyroidism in pregnant women is $17.3 \%$ (13.4\% subclinical hypothyroidism and $3.9 \%$ overt hypothyroidism). Present results are in accordance with the previous study where the prevalence of hypothyroidism has been observed as $20.1 \%$. It has been observed that hypothyroidism has a statistically significant relationship with recurrent pregnancy loss in first trimester and has also been suggested the early diagnosis of hypothyroidism could prevent recurrent pregnancy loss. ${ }^{14}$ Subclinical hyperthyroidism is the most frequent thyroid dysfunction occurring in pregnancy affecting approximately $1.5 \%$ of all pregnant women. ${ }^{15}$ Subclinical hypothyroidism can be defined as normal $\mathrm{fT}_{4}$ level with high TSH level. It has been observed that subclinical hypothyroidism in pregnancy has been associated with adverse maternal outcomes including miscarriages, pre-eclampsia, eclampsia, placental abruption, preterm labor and postpartum haemorrhage in mother whereas impaired neurological development in fetus. ${ }^{6,16,17}$ Several studies have claimed the relationship of TSH with pregnancy loss and with the incidence of child loss augmented by $60 \%$ for every doubling in TSH levels. ${ }^{18}$ It shows the importance of TSH in evaluating the pregnant women as regards to thyroid dysfunction. In the present study, the incidence of subclinical hypothyroidism was found to be $13.4 \%$, which is in agreement with the previous study carried out by Dhanwal et al. 19 where higher incidences were mentioned in North Indian population.

Iodine deficiency is very common in pregnant women as early pregnancy is characterized by a rapid surge in thyroid hormone production and iodine requirements. ${ }^{20}$ In addition, the fetal thyroid starts synthesizing thyroid hormone after 12 weeks of gestation, but before this period any demand from fetus is met by the maternal reserves. ${ }^{21,22}$ In the present study, we found that 66 out of 380 pregnant women $(17.4 \%)$ had hypothyroxinemia. 
The exact cause for this condition is not known fully but iodine deficiency is the major contributing factor. ${ }^{23}$ In different surveys conducted by the Directorate General of Health Services have been observed that 263 districts out of 325 studied are iodine deficiency disorders (IDD)endemic, i.e the prevalence of IDD is above $10 \%$ in the population. ${ }^{24}$ It was also noted that a significant iodine deficiency in pregnant women was observed from a review of available studies in India. ${ }^{25}$

The districts which are earlier found endemic to iodine deficiency have adequate iodine nutriture after salt iodisation programme. ${ }^{26}$ However, the iodine deficiency possibly due to the close vicinity to the coastal region where the salt is produced by solar evaporation of the sea water and is generally consumed in non-iodized form. ${ }^{27}$ Currently, iodized salt/table salt, breads/grains, and dairy products are the major sources of dietary iodine. ${ }^{28}$ However, the current push to lessen salt intake in order to lower the risks such as hypertension, cardiovascular disease as well as increasing intake of noniodized salts and sea salts have reasonably reduced dietary iodine intake in both rural and urban population. ${ }^{29,30}$

It has been observed that levels of fT4 decline throughout pregnancy. ${ }^{31}$ In the present study, the fT4 levels decline from first trimester to third trimester and the data was statistically significant $(p<0.05)$. It can be attributed to the increased binding of the thyroid hormones to TBG which makes the fT4 to be reduced with the advancement of pregnancy.

The American College of Obstetricians and Gynecologists and the clinical practice guidelines of the Endocrine Society recommended the investigation of thyroid function only in women with symptoms of thyroid disease or any previous history of thyroid disease and other associated conditions. ${ }^{32}$

In the present study, it has been noticed that $14(27.5 \%)$ out of 51 subclinical hypothyroids were in low-risk group signifying the need for universal screening for thyroid dysfunction in pregnant women. Otherwise, we would have missed the subclinical hypothyroidism cases in lowrisk group.

\section{CONCLUSION}

In conclusion, our current study shows that the high prevalence of thyroid dysfunction particularly subclinical hypothyroidism in low-risk pregnant women. Due to adverse pregnant outcome, it is recommended that all the pregnant women may be screened for thyroid dysfunction to reduce the maternal and neonatal morbidity in our Northern Andhra Pradesh population.

Funding: No funding sources Conflict of interest: None declared

Ethical approval: The study was approved by the Institutional Ethics Committee

\section{REFERENCES}

1. El Baba KA and Azar ST. Thyroid dysfunction in pregnancy. Int J Gen Med. 2012;5:227-30.

2. Skjoldebrand L, Brundin J, Carlstrom A. Thyroid associated components in serum during normal pregnancy. Acta Endocrinol. 1982;100(4):504-11.

3. Boss AM and Kingstone D. Further observations on serum free thyroxine concentrations during pregnancy. $\mathrm{Br}$ Med J (Clin res ed). 1981;283(6291):584.

4. Hopton MR, Ashwell K, Scott IV. Serum free thyroxine concentration and free thyroid hormone indices in normal pregnancy. Clin Endocrinol. 1983;18:431-7.

5. Nambiar V, Jagtap VS, Sarathi V, Lila AR, Kamalanathan S, Bandgar TR, et al. Prevalence and impact of thyroid disorders on maternal outcome in Asian-Indian pregnant women. J Thyroid Res. 2011;2011:4290-97.

6. Brain M. Thyroid disease in pregnancy. Obstet Gynecol. 2006;108(5):1283-92.

7. Reid SM, Middleton P, Cossich MC, Crowther CA, Bain E. Interventions for clinical and subclinical hypothyroidism in pregnancy. Cochrane Database of Systematic Reviews. 2010;7:1-34.

8. Bona G, Prodam F, Monzani A. "Subclinical hypothyroidism in children: natural history and when to treat". J Clin Res Pediatr Endocrinol. (Review). 2013;5,1(4):23-8.

9. Chang DLF and Pearce EN. Screening for maternal thyroid dysfunction in pregnancy: A review of the clinical evidence and current guidelines. Journal of Thyroid Research. 2013;2013.

10. Sahu MT, Das V, Mittal S, Agarwal A, Sahu M. Overt and subclinical thyroid dysfunction among Indian pregnant women and its effect on maternal and fetal outcome. Arch Gynecol Obstet. 2010; 281:215-20.

11. Stagnaro-Green A. Thyroid antibodies and miscarriage: Where are we at a generation later? J Thyroid Res. 2011;2011:841949.

12. Mannisto T, Vaarasmaki M, Pouta A, Hartikainen AL, Ruokonen A, Surcel HM, et al. Perinatal outcome of children born to mothers with thyroid dysfunction or antibodies: A prospective populationbased cohort study. J Clin Endocrinol Metab. 2009;94:772-9.

13. Wang W, Teng W, Shan Z, Wang S, Li J, Zhu L, et al. The prevalence of thyroid disorders during early pregnancy in China: The benefits of universal screening in the first trimester of pregnancy. Eur $\mathbf{J}$ Endocrinol. 2011;164:263-68.

14. Rao VR, Lakshmi A, Sadhani MD. Prevalence of hypothyroidismin recurrent pregnant loss in first trimester. Indian J Med Sci. 2008 62(9):357-61.

15. Casey BM and Leveno KJ. Thyroid disease in pregnancy. Obstet Gynecol. 2006;108:1283-92.

16. Allan WC, Haddow JE, Palomaki GE, Williams JR, Mitchell ML, Hermos RJ, et al. Maternal thyroid 
deficiency and pregnancy complications: implications for population screening. J of Med Screen. 2000;7:127-30.

17. Abalovich M, Gutierrez S, Alcaraz G, Maccallini G, Garcia A, Levalle O. Overt and subclinical hypothyroidism complicating pregnancy. Thyroid. 2002;12:63-8.

18. Benhadi N, Wiersjnga WM, Reitsma JB, Vrijkotte TG, Bonsel GJ, et al. Higher maternal TSH levels in pregnancy are associated with increased risk for miscarriage, foetal or neonatal death. Eur $\mathrm{J}$ of Endocrinol. 2009;160:985-91.

19. Dhanwal DK, Prasad S, Agarwal AK, et al. High prevalence of subclinical hypothyroidism during first trimester of pregnancy in North India. Indian $\mathbf{J}$ Endocrinol Metab. 2013;17:281-84.

20. Glinoer D. The importance of iodine nutrition during pregnancy. Public Health Nutr. 2007;10(12A):154246.

21. de Escobar GM, Obregon MJ, del Rey FE. Maternal thyroid hormones early in pregnancy and fetal brain development. Best Pract Res Clin Endocrinol Metab. 2004; 18:225-48.

22. Kilby MD. Thyroid hormones and fetal brain development. Clin Endocrinol. 2003;59:280-81.

23. Morreale EG, Obregon MJ, Escobar RF. Role of thyroid hormone during early brain development. Eur J Endocrinol. 2004;151(Suppl 3):U25-U37.

24. Ministry of Health and Family Welfare, Government of India; 2011. [accessed on July 1, 2011]. Department of Health and Family Welfare, New Delhi. Annual Report 2010-2011.

25. Kapil Y, Srivastava R, Badhal S, Palanivel C, Pandav CS, Karmarkar MG. Review of iodine nutrition of pregnant women in India: evidence of significant iodine deficiency. Indian $\mathrm{J}$ Med Specialties. 2012;3:49-54.
26. Kapil U, Singh P, Pathak P. Current Status of Iodine Nutriture and Iodine Content of Salt in Andhra Pradesh. Indian Pediatr. 2004;41:165-69.

27. Kapil U, Singh P, Dwivedi SN. Ind J of Physiol Pharmacol. 2005;49(1):369-72.

28. Murray CW, Egan SK, Kim H, Beru N, Bolger PM. US Food and Drug Administration's Total diet Study: dietary intake of perchlorate and iodine. J Expo Sci Environ Epidemiol. 2008;18(6):571-80.

29. Dasgupta PK, Liu Y, Dyke JV. Iodine nutrition: iodine content of iodized salt in the United States. Environ Sci Technol. 2008;42(4):1315-23.

30. Lee SY, Leung AM, He X, Braverman LE, Pearce EN. Iodine content in fast foods:comparison between two fast-food chains in the United States. Endocr Pract. 2010;16(6):1071-72.

31. Zarghami N, Rohbani-Noubar M, Khosrowbeygi A. Thyroid hormones status during pregnancy in normal Iranian women. Indian $\mathbf{J}$ Clin Biochem. 2005;20(2):182-5.

32. de Groot L, Abalovich M, Alexander EK. Management of thyroid dysfunction during pregnancy and postpartum: an Endocrine Society clinical practice guideline. J Clin Endocrinol Metab. 2012;97:2543-65.

Cite this article as: Krishnamma B, Prabhavathi V, Prasad DKV. Prevalence of thyroid dysfunction in pregnant women and the need for universal screening: an observational study in northern Andhra Pradesh population. Int J Reprod Contracept Obstet Gynecol 2017;6:2536-40. 